\title{
Danube River Basin Waters on Romanian Territory: Chemical Status Assessment Based on Priority Substances Data Analysis
}

\begin{abstract}
ANA MARIA ANGHEL*, GYORGY DEAK, PETRA IONESCU, CRISTINA CIMPOERU, IRINA CIOBOTARU, ECATERINA MARCU, BOGDAN URITESCU, LUCIAN LUMINAROIU, BIANCA PETCULESCU, VIOLETA MONICA RADU, GABRIEL BADEA

National Institute for Research and Development in Environmental Protection - INCDPM, 294 Splaiul Independenei, 060031, Bucharest, Romania

Framework Directive (2000/60/EC) (WFD) sets out a series of legal measures at European level against surface waters chemical pollution. The EU-list, annex of the WFD, contains those substances that present a significant risk to human health via aquatic environment, known as priority substances. In the last ten years, the Danube water quality has improved significantly. Instead, heavy metals concentrations in the tributaries waters sometimes were found to be rather highest and the chemical status is not in-line with the WFD requirements. Therefore, the Danube River Basin (DRB) waters quality show ed a significant variability in terms of priority substances due to the diverse human activities, especially mining activities. This research paper aims to assess the chemical status of the DRB waters located on Romania territory regarding six heavy metals: $\mathrm{Pb}, \mathrm{Cd}, \mathrm{Ni}, \mathrm{Cr}, \mathrm{Cu}$, and $\mathrm{Zn}$ by analysing water and sediment samples collected from different areas (south-west and north-west of Romania). Based on the obtained results by evaluating the quality elements, the water chemical status of DRB achieved a good chemical status for $74 \%$ of water samples and $55 \%$ of sediment samples. Also, the basic statistic and multivariate analysis were used to explore the relationship between the concentration values obtained for priority substances to underlying the water quality assessment.
\end{abstract}

Keywords: Water Framework Directive; Danube River Basin waters; priority substances; heavy metals

The human activities play a vital role in order to protect the aquatic environment, first of all, by respecting the water politics, often known as hydropolitics. Thereby, compliance with these policies is directly related to human development $[1,2]$. The most important instrument of European environmental legislation that focuses on understanding and ensuring sustainable water governance still remains the Water Framew ork Directive 60/2000/CE (WFD) until its upcoming review in 2019. [3-7]. The WFD specifies the establishment of the ecological status or/and chemical status of the surface waters category that not meet the environmental objectives. The chemical status is based on the water and sediment quality standards of certain indicators that have been identified as of significant risk to or via the aquatic environment [8].

Industrial activities, especially the mining, have become a global concern due to the local and regional degradation of life quality by polluting the water, degrading the fertile land and lowering the air quality. Issues as the polymetallic tailing dumps and mining wastewater from the mining processes, can lead to depletion of natural resources and therefore require special attention in the context of sustainable management [9-12]. It is known that the Romanian mining industry has a long tradition in this field and the environmental issues still exists [13]. Actualy, various alternatives to transform industrial wastes in secondary raw materials are studied in the context of the issue of natural resource depletion [14].

The surface waters studied in this paper belong to the Danube River Basin (DRB), that is the second largest and the most important basin in Europe [15]. The Romanian Danube River section is the general wastewater collector from the all countries it crosses until it flows into the Black Sea. [16]. Cadmium and lead were considered as the most serious inorganic microcontaminants in the Danube River Basin. The pollution of the Danube River and its major tributaries by nickel and zinc was found to be rather low, excepting in the lower Danube section. For zinc the noncompliance with the target value in the lower Danube was not very frequent, the limit was exceeded by 20 $100 \%$. Nickel concentrations in the whole Danube River did not go over the target limit during 1996 -2000 [17]. In this context and because the Danube is an important transportation corridor for Europe, this paper deals with chemical status assessment of the DRB waters located on Romanian territory in terms of priority substances -heavy metals (HM).

\section{Experimental part}

To obtain the data, the following activities were pursued: the selection of the surface waters that are part of the DRB located on Romanian territory; collection, preservation and handling of water and sediment samples; laboratory analysis on collected water and sediment samples; the selection of the elements and quality standards of national legislation in force for establishing the chemical status of monitored surface water; the selection of the statistical methods which have been used for water quality assessment.

\section{Studied area}

The studied surface waters belonging to Somes-Tisa and Banat catchment areas on the Northwest and Southwest regions of Romania. Regarding the waters of Somes-Tisa catchment area, were studied: Somes, Tur, Tur, Batarci, Stramba, Socea, Tarna Mare from Satu Mare County and Lapus from Maramures County. The Bo'neag waters from Caras-Severin County were studied, which belong to the Banat catchment area and is the direct affluent of the Danube, having the confluence with the river in the vicinity of the Moldova Veche settlement. Also, was taken into consideration the Lower Danube water near

*email: maria.anaanghel@gmail.com; ana6209@yahoo.com 


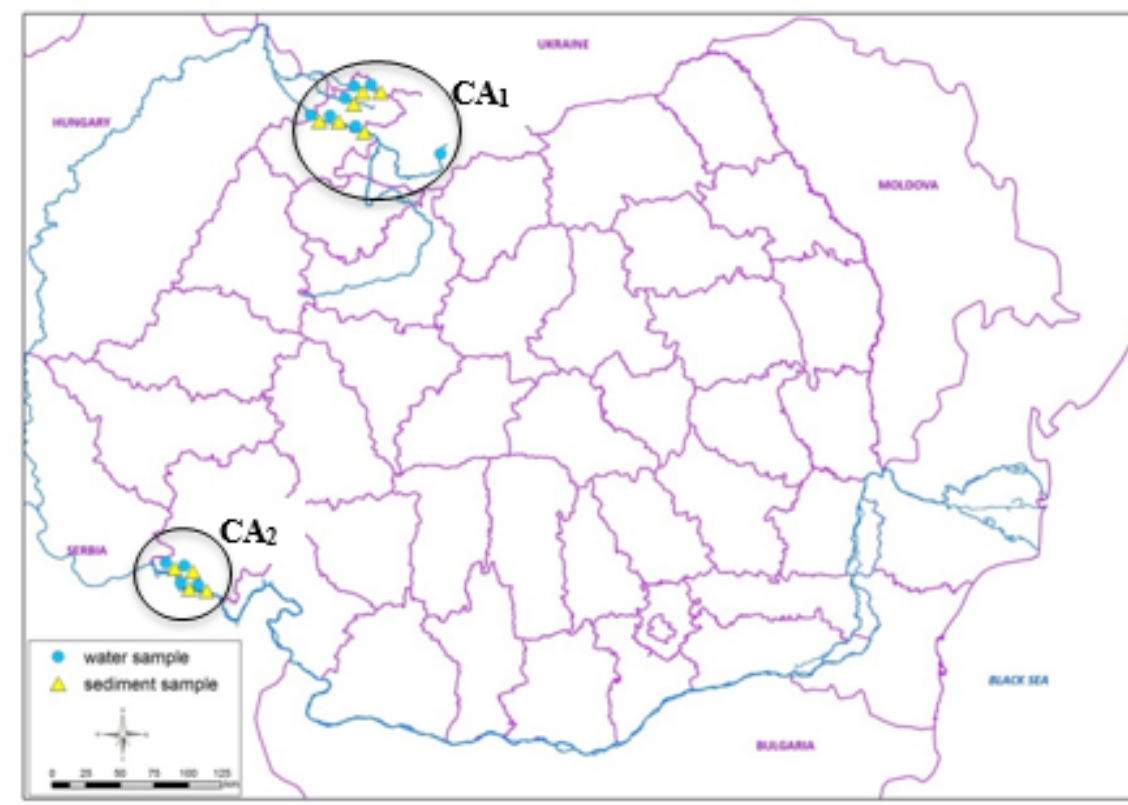

Fig. 1. Identification of DRB catchment areas on Romanian territory to which monitored surface waters belong

the leftbank between Coronini and Pojejena, which delimits the southern extremity of the Banat catchment area. The two selected areas were noted $\mathrm{CA}_{1}$ and $\mathrm{CA}_{2}$ and can be viewed in figurel.

\section{Sample collection, preservation and handling}

The sampling it is an important procedure due to the systematic errors that can appear and tend to influence the measurement. In order to avoid any difficulties on the fieldwork and to carry out in good conditions the water and sediment sampling campaigns, as well as their analysis in optimal conditions, the selected areas were thoroughly studied in advance, mainly taking into account the access to each surface water at the sampling point, water depth and velocity, also the weather conditions. A total of 40 water samples and 20 sediment samples from the two studied areas $\left(\mathrm{CA}_{1} ; \mathrm{CA}_{2}\right)$ were taken during 2017.

In-situ measurements were performed for temperature, turbidity, $\mathrm{pH}$, flow, depth, conductivity, etc. using a multiparameter sensor Eureka Manta 2 (fig. 2). The sample and equipment transport were carried out with the INCDPM AutoLab - National Institute for Research and Development in Environmental Protection mobile laboratory - used to monitor water and soil quality indicators (fig. 2). Prior to field dispatch, the multiparameter sensor was calibrated and the sampling recipients were checked in order to meet the sampling requirements specified in SR EN ISO 56676:2017 [18] and SR ISO 5667-12:2001 [19] standards. To identify correctly and easily the samples, the recipient was labeled and dated. Each recipient perfectly clean, made of polyethylene with a screw / cap stopper and hermetically sealed was used to ensure an optimum transport. Once in the laboratory, all samples were subjected to the procedures for determining the HM indicators.
Monitored parameter and laboratory analytical method Six priority substances were selected for this study: $\mathrm{Pb}$, $\mathrm{Cd}, \mathrm{Ni}, \mathrm{Cr}, \mathrm{Cu}$, and $\mathrm{Zn}$. The method used for the HM determination was flame atomic absorption spectrometry using a high-resolution continuum source AAS spectrometer (contrAA 700, Analytik Jena, Germany).

The water samples with low organic content and low turbidity were acidified using concentrated $\mathrm{HNO}_{3}$. In the case of samples with high organic content or high turbidity, acid digestion was performed using concentrated $\mathrm{HNO}_{3}$ in an open system. $100 \mathrm{~mL}$ of water samples and $10 \mathrm{~mL}$ $\mathrm{HNO}_{3}$ were introduced in a glass beaker and heated on a hot plate until the complete digestion of the sample avoiding complete evaporation. After digestion, the samples were filtered and brought to $100 \mathrm{~mL}$ with $\mathrm{HNO}_{3}$ solution $\sim 0.5 \%(\mathrm{v} / \mathrm{v})$.

The sediment samples were dried at ambient temperature, milled and sieved through a $63 \mu \mathrm{m}$-sieve (fig. 3). $0.5 \mathrm{~g}$ of sediment were digested with aqua regia ( $3 \mathrm{~mL}$ concentrated $\mathrm{HNO}_{3}$ and $9 \mathrm{~mL}$ concentrated $\mathrm{HCl}$ ) on a sand bath. After the digestion, the sediment samples were filtered and brought to $100 \mathrm{~mL}$ with $\mathrm{HNO}_{3}$ solution $\sim 0.5 \%$ (v/v).

Both water and sediment samples were analysed as prepared or after proper dilution (if needed).

The detection limits were $0.0080 \mathrm{mg} / \mathrm{L}(1.6 \mathrm{mg} / \mathrm{kg}$ for sediment) for $\mathrm{Pb}, 0.0010 \mathrm{mg} / \mathrm{L}$ ( $0.2 \mathrm{mg} / \mathrm{kg}$ for sediment) for Cd, $0.0040 \mathrm{mg} / \mathrm{L}$ ( $0.8 \mathrm{mg} / \mathrm{kg}$ for sediment) for $\mathrm{Ni}, 0.0100$ $\mathrm{mg} / \mathrm{L}$ (2 mg/kg for sediment) for $\mathrm{Cr}, 0.0080 \mathrm{mg} / \mathrm{L}(1.6 \mathrm{mg} /$ $\mathrm{kg}$ ) for Cu, and $0.0020 \mathrm{mg} / \mathrm{L}(0.4 \mathrm{mg} / \mathrm{kg}$ for sediment) for Zn.

Quality control. A representative spike concentration was selected for each HM to be measured. Using stock standards, a quality control check sample were prepared.

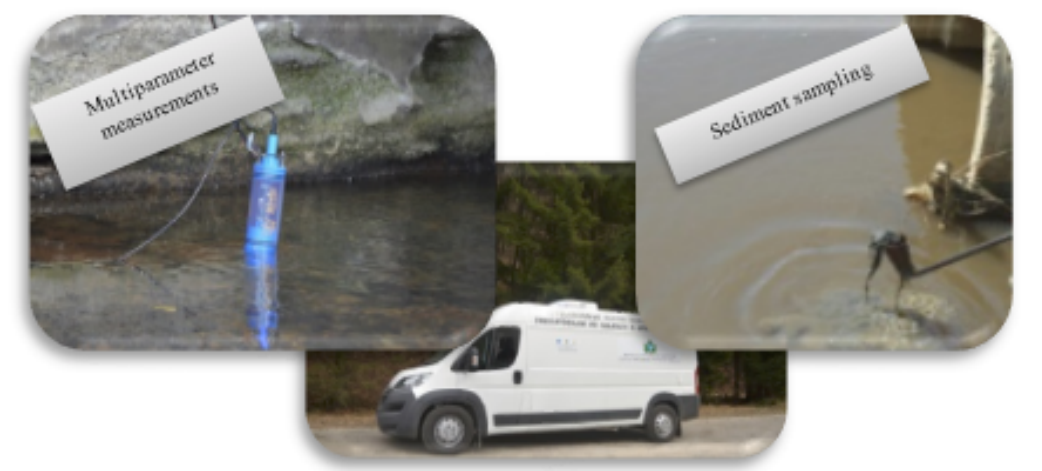

Fig. 2. INCDPM AutoLab. In-situ measurements and the sediment collection procedure from rivers 


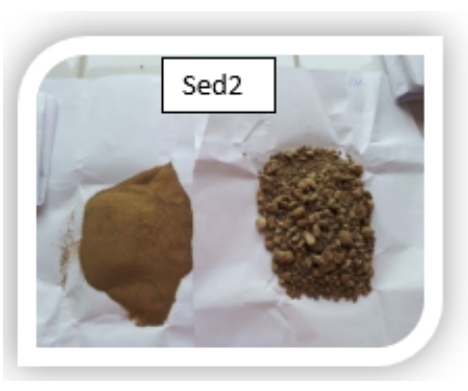

Variable assessment

In this paper, the legislative reference for establishing the chemical status of monitored surface water is the Order no. 161/2006 [20]. This Ministerial Order (MO 161/ 2006) is the Romanian normative act that partial ensures transposition/implementation of WFD [20]. To assess the chemical status, the MO 161/2006 provides two states: good chemical status - compliance with the quality standards and bad chemical status - overcoming the quality standards [20]. For the considered water quality variables - HM, in Table 1 are presented the standards, both for water and sediment.

The use of statistics in environmental assessments has become an increasingly common practice in the research studies to draw valid conclusions [21]. The quantitative analysis of the obtained data was done using statistical methods. Thus, for the basic features description, basic statistics were performed, which provided simple data on each type of sample under analysis, i.e. the values of water and sediment concentrations. Pearson's correlation analysis was used to dataset obtained in order to certify the association among HM. Statistical data set analyses were performed with Minitab 17 software.

\section{Results and discussions \\ Chemical status}

According to the information provided by the literature, the ecological status, the ecological potential and the chemical status of DRB rivers in 2009 from a total of 681 assessed water bodies, a percent of $28 \%$ achieved a good ecological or ecological potential, and $64 \%$ of the water bodies achieved a good chemical status [22]. In this research study, for assessing the water quality status, the HM concentration levels obtained were compared to the standard levels. Table 3 presents the good chemical status achieved by the water bodies studied, in percent, based on the priority substances determination from water and sediment samples collected. Also, a visual identification of the sample points which achieved a good chemical status is showed in figure 4 and figure 5 .

The analysis shows that, in the two studied areas CA1 and $C A 2$, the pollution from industrial activities can pose a significant health threat caused by residential and agricultural uses, especially in areas where high parameters value were found. The copper levels in all the water samples were above the natural and maximum permissible concentration. Zinc concentration level for water is not standardized, buthas been mapped by creating

\begin{tabular}{|c|c|c|c|c|}
\hline \multirow{2}{*}{ Element } & \multicolumn{2}{|c|}{ Unit } & \multicolumn{2}{c|}{ Quality Standard } \\
\cline { 2 - 5 } & Water & Sediment & Water & Sediment \\
\hline Cadmium & $\mu \mathrm{g} / \mathrm{L}$ & $\mathrm{mg} / \mathrm{kg}$ & 1.0 & 0.8 \\
\hline Chromium & $\mu \mathrm{g} / \mathrm{L}$ & $\mathrm{mg} / \mathrm{kg}$ & 2.5 & 100 \\
\hline Copper & $\mu \mathrm{g} / \mathrm{L}$ & $\mathrm{mg} / \mathrm{kg}$ & 1.3 & 40 \\
\hline Nickel & $\mu \mathrm{g} / \mathrm{L}$ & $\mathrm{mg} / \mathrm{kg}$ & 2.1 & 35 \\
\hline Lead & $\mu \mathrm{g} / \mathrm{L}$ & $\mathrm{mg} / \mathrm{kg}$ & 1.7 & 85 \\
\hline Zinc & $\mu \mathrm{g} / \mathrm{L}$ & $\mathrm{mg} / \mathrm{kg}$ & - & 150 \\
\hline
\end{tabular}

Table 1

LEGAL CRITERIA FOR CONTROLLING THE SURFACE WATER POLLUTION IN THE ROMANIA TERRITORY FROM A VARIETY OF SOURCES [20]

Table 2

INTERPRETATION CRITERIA OF r'S AND p'S VALUES [5]

\begin{tabular}{|c|c|}
\hline Value & Interpretation \\
\hline \multicolumn{2}{|l|}{$r$} \\
\hline 0.90 to $1.00(-0.90$ to -1.00$)$ & Very high positive/negative correlation - VHP/NC \\
\hline 0.70 to $0.90(-0.70$ to -0.90$)$ & High positive/negative correlation - $\mathrm{HP} / \mathrm{NC}$ \\
\hline 0.50 to $0.70(-0.50$ to -0.70$)$ & Moderate positive/negative correlation - MP/NC \\
\hline 0.30 to $0.50(-0.30$ to -0.50$)$ & Low positive/negative correlation - LP/NC \\
\hline 0.00 to $0.30(0.00$ to -0.30$)$ & Negligible correlation $-\mathrm{NgC}$ \\
\hline \multicolumn{2}{|l|}{ p-value } \\
\hline$=0.05$ or $<0.05$ & Statistical significance correlation ( $95 \%$ confidence level) \\
\hline$=0.01$ or $=(0.01-0.001)$ & Highly significant correlation ( $99 \%$ confidence level) \\
\hline$=(0.001-0.000)$ & Very high significance correlation ( $99 \%$ confidence level) \\
\hline$>0.05$ & Insignificant correlation \\
\hline
\end{tabular}

Table 3

COMPARISON OF RESULTS OBTAINED FOR WATER SAMPLES WITH THE LEGAL CRITERIA

\begin{tabular}{|c|c|c|}
\hline \multirow{2}{*}{ Element } & \multicolumn{2}{|c|}{ Percent(\%) } \\
\cline { 2 - 3 } & Water & Sediment \\
\hline Cadmium & 88.46 & 20.00 \\
\hline Chromium & 100.00 & 95.00 \\
\hline Copper & 0.00 & 55.00 \\
\hline Nickel & 80.77 & 85.00 \\
\hline Lead & 73.08 & 85.00 \\
\hline Zinc & - & 20.00 \\
\hline
\end{tabular}



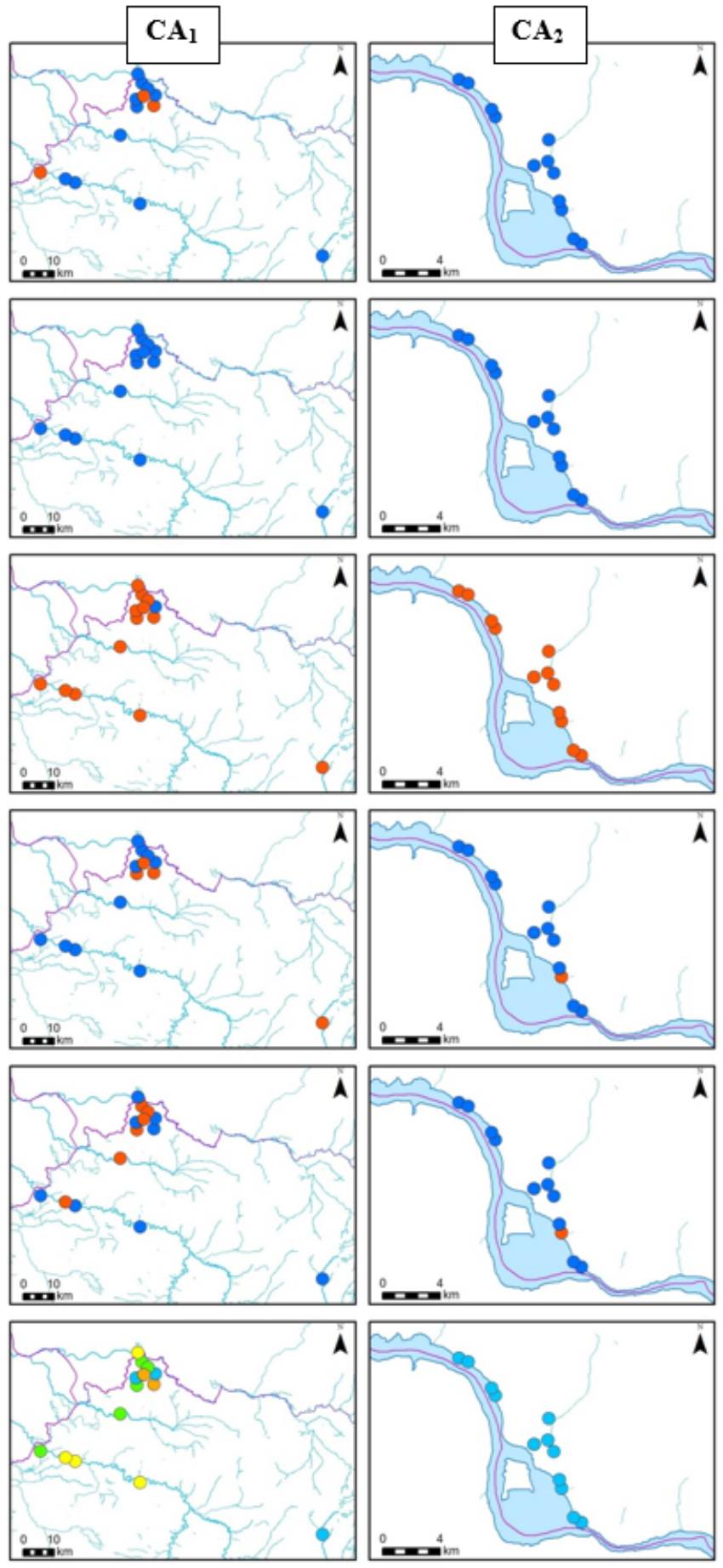

intervals marked with different colours, as it is illustrated in Figure 4. Hence, the major difference between the first interval $(1-20 \mu \mathrm{g} / \mathrm{L} \mathrm{Zn})$ and the last $(251-15800 \mu \mathrm{g} / \mathrm{L} \mathrm{Zn})$ it is obvious. In the sediment samples, cadmium and zinc have the most concentration values above maximum quality standard.

\section{Water quality statistical analysis}

By displaying the Descriptive Statistics a summary of information for available data set was provided and are shown in Table 4. Were calculated the measures of central tendency (mean and median) to describe the whole set of the obtained data with a single value and, also, the measures of variability (variance, standard deviation, coefficient of variation) to observe if the values tend to cluster together or if they tend to be spread out. Analysing the minimum and maximum of each indicator, there was observed a very large difference between the two values

\section{Cd}

- In Quality Standard

- Over Quality Standard

$\mathrm{Cr}$

- In Quality Standard

$\mathrm{Cu}$

- In Quality Standard

- Over Quality Standard

Fig. 4. Concentration levels obtained compared to legal criteria for water
$\mathrm{Ni}$

- In Quality Standard

- Over Quality Standard

$\mathrm{Pb}$

- In Quality Standard

- Over Quality Standard
$\mathrm{Zn}(\mu \mathrm{g} / \mathrm{l})$

- $1-20$

- $21-100$

- $101-250$

- $251-15800$

for both water samples and sediment samples. This indicates the presence of point sources of heavy metal pollution and that samples have been taken from different points. Based on the mean concentrations, the HM in the studied surface waters exhibited the following descending order: $\mathrm{Zn}>\mathrm{Cu}>\mathrm{Ni}>\mathrm{Pb}>\mathrm{Cd}>\mathrm{Cr}$ - in the water samples; $\mathrm{Zn}>\mathrm{Cu}>\mathrm{Pb}>\mathrm{Cr}>\mathrm{Ni}>\mathrm{Cd}$ - in the sediment samples. In another paper, was found that the general profile of the mean metals concentrations in sediments of the Danube River waters (between Km 347 and $\mathrm{Km}$ 182) as beeing $\mathrm{Zn}>\mathrm{Cr}>\mathrm{Cu}>\mathrm{Ni}>\mathrm{Pb}>\mathrm{Cd}$ [23].

The linear relationship that exists between the HM variables in the collected samples, based on the concentration values, was checked with the Pearson product-moment correlation coefficient. Thereby, it was displayed the $r$ (Pearson's correlation coefficient) and $p$ value (the value that indicates a significant correlation between the elements [5]) forming the Pearson's matrix showed in Table 5. Based on samples concentration values, 

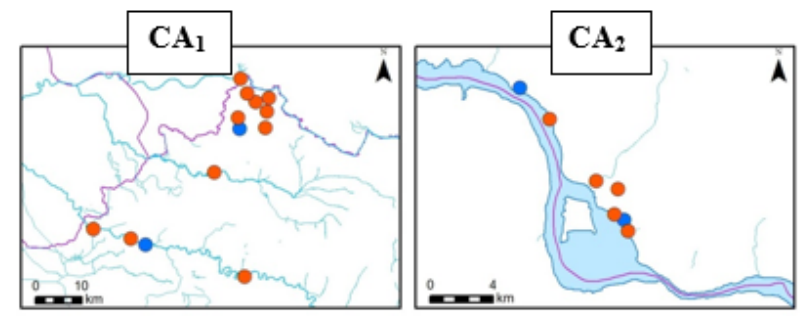

Cd In Quality Standard
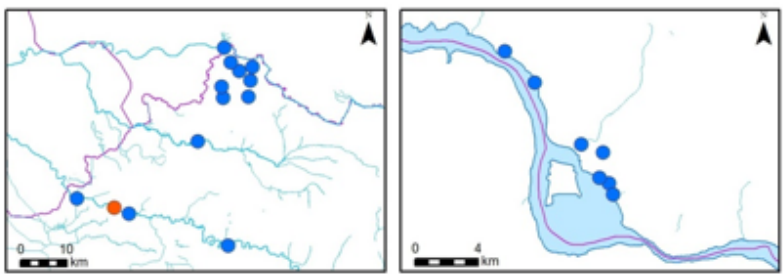

- Over Quality Standard
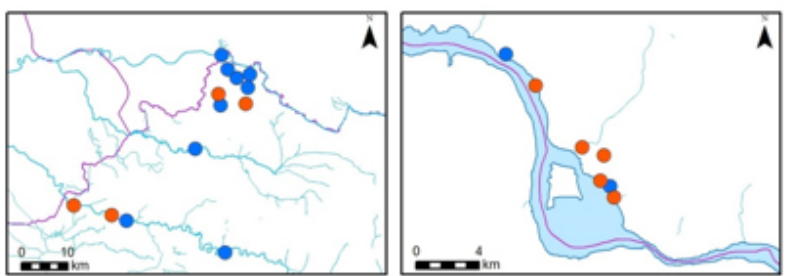

Cr
- In Quality Standard
- Over Quality Standard
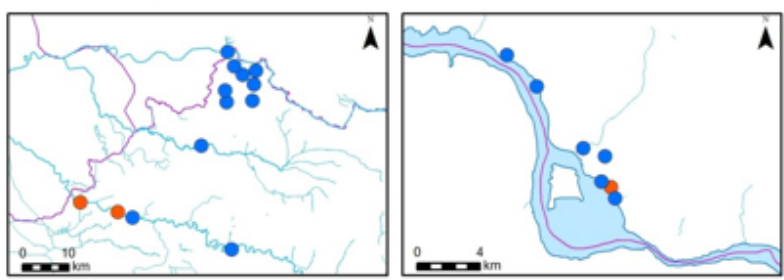
$\mathrm{Cu}$
- In Quality Standard
- Over Quality Standard

$\mathrm{Ni}$

- In Quality Standard

- Over Quality Standard

$\mathrm{Pb}$

- In Quality Standard

- Over Quality Standard

$\mathrm{Zn}$

- In Quality Standard

- Over Quality Standard
Fig. 5. Concentration levels obtained compared to legal criteria for sediment

Table 4

QUANTITATIVE DESCRIPTIONS OF THE WATER $(\mu \mathrm{g} / \mathrm{L})$ AND SEDIMENT $(\mathrm{mg} / \mathrm{kg})$ CONCENTRATION VALUES

\begin{tabular}{|c|c|c|c|c|c|c|c|c|}
\hline \multirow{2}{*}{ Variable } & Unit & $\begin{array}{c}\text { Total } \\
\text { Count }\end{array}$ & Mean & StDev & Variance & CoefVar & Min $\rightarrow$ Max & Median \\
\hline \multirow{2}{*}{$C d$} & $\mu \mathrm{g} / \mathrm{L}$ & 26 & 2.1 & 7.8 & 51.4 & 342.1 & $0.001 \rightarrow 32.7$ & 0.04 \\
\cline { 2 - 9 } & $\mathrm{mg} / \mathrm{kg}$ & 20 & 1.6 & 0.8 & 0.7 & 51.9 & $0.3 \rightarrow 2.9$ & 1.4 \\
\hline \multirow{2}{*}{$\mathrm{Cr}$} & $\mu \mathrm{g} / \mathrm{L}$ & 26 & 0.5 & 0.6 & 0.3 & 120.6 & $0.01 \rightarrow 2.0$ & 0.2 \\
\cline { 2 - 9 } & $\mathrm{mg} / \mathrm{kg}$ & 20 & 49.8 & 104.5 & 10911.1 & 209.6 & $2.0 \rightarrow 488.6$ & 27.8 \\
\hline \multirow{2}{*}{$\mathrm{Cu}$} & $\mu \mathrm{g} / \mathrm{L}$ & 26 & 16.3 & 35.6 & 1266.4 & 219.0 & $1.4 \rightarrow 147.8$ & 4.0 \\
\cline { 2 - 9 } & $\mathrm{mg} / \mathrm{kg}$ & 20 & 191.7 & 392.3 & 153909.0 & 204.6 & $18.8 \rightarrow 1570.2$ & 37.7 \\
\hline \multirow{2}{*}{$\mathrm{Ni}$} & $\mu \mathrm{g} / \mathrm{L}$ & 26 & 5.2 & 14.9 & 222.4 & 285.9 & $0.004 \rightarrow 69.9$ & 0.9 \\
\cline { 2 - 9 } & $\mathrm{mg} / \mathrm{kg}$ & 20 & 23.9 & 14.5 & 210.4 & 60.7 & $4.0 \rightarrow 61.9$ & 23.7 \\
\hline \multirow{2}{*}{$\mathrm{Pb}$} & $\mu \mathrm{gg} / \mathrm{L}$ & 26 & 2.4 & 3.9 & 15.1 & 162.4 & $0.008 \rightarrow 15.5$ & 1.0 \\
\cline { 2 - 9 } & $\mathrm{mg} / \mathrm{kg}$ & 20 & 116.1 & 286.1 & 81848.3 & 246.5 & $13.5 \rightarrow 1315.0$ & 51.2 \\
\hline \multirow{2}{*}{$\mathrm{Zn}$} & $\mu \mathrm{g} / \mathrm{L}$ & 26 & 1249.0 & 4261.0 & 18156657.0 & 341.2 & $1.0 \rightarrow 15772.0$ & 9.0 \\
\cline { 2 - 9 } & $\mathrm{mg} / \mathrm{kg}$ & 20 & 365.7 & 296.8 & 88106.4 & 81.2 & $56.1 \rightarrow 1049.7$ & 245.8 \\
\hline
\end{tabular}


Table 5

PEARSON'S MATRIX FOR WATER AND SEDIMENT CONCENTRATION VALUES

\begin{tabular}{|c|c|c|c|c|c|c|c|c|c|c|c|c|}
\hline $\begin{array}{c}\text { water } \\
\mathrm{E}^{*} \rightarrow \\
\downarrow\end{array}$ & $\mathrm{Cd}$ & $\mathrm{Pb}$ & $N i$ & $Z n$ & $\mathrm{Cr}$ & Coeff*: & $C d$ & $\mathrm{Cu}$ & $\mathrm{Ni}$ & $\mathrm{Pb}$ & $Z n$ & $\begin{array}{c}\text { sediment } \\
\leftarrow \mathrm{E}^{*} \\
\downarrow\end{array}$ \\
\hline \multirow{2}{*}{$\mathrm{Pb}$} & 0.585 & & & & & $r$ & 0.154 & & & & & \multirow{2}{*}{$\mathrm{Cu}$} \\
\hline & 0.002 & & & & & p-value & 0.516 & & & & & \\
\hline \multirow{2}{*}{$N i$} & 0.809 & 0.284 & & & & $r$ & 0.030 & 0.008 & & & & \multirow{2}{*}{$N i$} \\
\hline & 0.000 & 0.160 & & & & p-value & 0.900 & 0.974 & & & & \\
\hline \multirow{2}{*}{$Z n$} & 0.956 & 0.459 & 0.944 & & & $r$ & -0.068 & 0.015 & -0.329 & & & \multirow{2}{*}{$P b$} \\
\hline & 0.000 & 0.018 & 0.000 & & & p-value & 0.777 & 0.949 & 0.157 & & & \\
\hline \multirow{2}{*}{$\mathrm{Cr}$} & -0.213 & -0.202 & -0.152 & -0.206 & & $r$ & 0.828 & 0.013 & -0.084 & -0.124 & & \multirow{2}{*}{$Z n$} \\
\hline & 0.296 & 0.323 & 0.460 & 0.313 & & p-value & 0.000 & 0,958 & 0,724 & 0,604 & & \\
\hline \multirow{2}{*}{$\mathrm{Cu}$} & 0.779 & 0.663 & 0.593 & 0.706 & -0.249 & $r$ & 0.280 & -0.065 & 0.720 & -0.102 & -0.072 & \multirow{2}{*}{$\mathrm{Cr}$} \\
\hline & 0.000 & 0.000 & 0.001 & 0.000 & 0.220 & p-value & 0.232 & 0.785 & 0.000 & 0.668 & 0.764 & \\
\hline
\end{tabular}

${ }^{8}$ Element. ${ }^{88}$ Coefficient.

\begin{tabular}{|c|c|c|c|c|c|}
\hline $\begin{array}{c}\mathrm{E}^{*} \rightarrow \\
+\end{array}$ & $\mathrm{Cd}$ & $\mathrm{Ni}$ & $\mathrm{Pb}$ & $\mathrm{Zn}$ & $\mathrm{Cr}$ \\
\hline $\mathrm{Cu}$ & $H P C / N g C$ & $M P C / N g C$ & $M P C / N g C$ & $H P C / N g C$ & $N g C / N g C$ \\
\hline $\mathrm{Ni}$ & $H P C / N g C$ & & & & \\
\hline $\mathrm{Pb}$ & $M P C / N g C$ & $N g C / L N C$ & & & \\
\hline $\mathrm{Zn}$ & $V H P C / H P C$ & $V H P C / N g C$ & $L P C / N g C$ & & \\
\hline $\mathrm{Cr}$ & $N g C / N g C$ & $N g C / H P C$ & $N g C / N g C$ & $N g C / N g C$ & \\
\hline
\end{tabular}

Table 6

PEARSON'S CORRELATION COEFFICIENT INTERPRETATION FOR WATER/SEDIMENT CONCENTRATION VALUES the resulting Pearson matrix shows a strongest statistically significant correlation between seven pairs of HM for water and two pairs of HM for sediment. It has been observed that the pair $\mathrm{Cd}-\mathrm{Zn}$ reacts in the same way both for water and sediment and having a very high significance correlation. The negative correlation between the some pairs of HM shows that the amounts of the two HM in one pair vary in opposite directions (in surface water matrix, the amount of one HM increases, and for the other HM decreases). After the computation Pearson matrix, the $r$ coefficient was interpreted according to Table 2 and it is shown in Table 6 . The HM that presents a statistical significant correlation with each other in the studied surface waters, suggested a common pollution source such as mining activities. It is well known the fact that the deposition of fine grained materials and organic matter physically controls the abundance and distribution of metals in sediments at distance from the source [21].

\section{Conclusions}

The analysis performed highlights the importance of this type of research study. The information obtained revealed that the industrial activities (mining) causes ecosystem disturbance on long term. These disturbances leads to an evitable fall out of industrialization and today's civilization, but mining still remains one of the main global economic activities.

Also, the study proves the utility of statistical methods application and above all the analysis and interpretation of the complex water quality data sets. The methods used have made it possible to identify the polluted areas and the distribution of pollutants along the studied water bodies for a better understanding into the temporal and spatial changes in water quality. On the basis of actual information on chemical status, may be improved the local governance for better environmental management. Hence, may be established new targets that can be included in the water analysis and planning tool (Management Plan), developed at the level of the entire Danube River Basin and which respects the Water Framework Directive requirements.

Acknowledgment: The data presented in this paper are part of a national project entitled Research on the cross-border dispersion of heavy metals in the Danube River Basin from Romania areas affected by extractive activities carried out during 2017 by the researchers from INCDPM (www.incdpm.ro). The first author wishes to thank the fieldwork and lab work teams for the effort made to successfully complete the project activities, and also to the General Director of INCDPM.

\section{References}

1. ANGHEL, A.M., DIACU, E., PETCULESCU, B., AES Bioflux, 7, no.2, 2015, p. 139.

2. ROGERS, S., CROW MILLER, B., WIREs Water, 4, no. 6, 2017, doi: 10.1002/wat2.1239

3. ANGHEL, A.-M., MARINESCU, F., ILIE, M., GHITA, G., IONESCU, $P_{.}$ MARCUS, I., TOCIU, C., DUMITRU, F. D., MITIU, M., POPESCU, I., SZEP, R., LASLO, L., HOLBAN E., JEPE, 18, no. 3, 2017, p.853.

4. RADU, V. M., DIACU, E., IONESCU, P., DEAK, G., Rev. Chim. (Bucharest), 66, no. 5, 2015, p.601.

5. ANGHEL, A.-M., ILIE, M., GHITA, G., MARINESCU, F., DEAK G., IJ ESD, 8, no. 2, 2017, p. 111, doi: 10.18178/ijesd.2017.8.2.931

6. IONESCU, P., RADU, V. M., SZEP, R., RAISCHI, M., BOBOC, M., 15th International Multidisciplinary Scientific GeoConference (SGEM), J une 18-24, 2015 - Albena, Proceedings paper, ISSN: 1314-2704, ISBN:978619-7105-36-0, 1, p. 129. 
7. BRACK, W., DULIO V., AGERSTRAND, M., ALLAN, I., ALTENBURGER, R., BRINKMANN, M., BUNKE, D., BURGESS, R. M., COUSINS, I., ESCHER, B. I., HERNANDEZ, F.J., HEWITT, L.M., HILSCHEROVA, K., HOLLENDER, J., HOLLERT, H., KASE, R., KLAUER, B., LINDIM, C., HERRAEZ, D.L., MIEGE, C., MUNTHE, J., O'TOOLE, S., POSTHUMA, L., RÜDEL, H., SCHÄFER, R. B., SENGL, M., SMEDES, F., VAN DE MEENT, D., VAN DEN BRINK, P. J., VAN GILS, J., VAN WEZEL, A. P., VETHAAK, A. D., VERMEIRSSEN, E., VON DER OHE, P. C., VRANA, B., Sci Total Environ., 576, 2017, p.720.

8. *** DIRECTIVE 2000/60/EC OF THE EUROPEAN PARLIAMENT AND OF THE COUNCIL, 23 October 2000, Official J ournal of the European Communities

9. MARCUS, M.-I., VLAD, M., MITIU, M. A., Adv Mat Res, 1143, p. 108, 2017, doi:10.4028/www.scientific.net/AMR.1143.108.

10. COCARTA, D. M., NEAMTU, S., RESETAR-DEAC, A.-M., IJEST, 13, no. 8, 2016, p. 2025.

11. STEFAN, D. S., NEACSU, N., PASCU, L. F., SERBANESCU, C., STEFAN, M., Rev. Chim. (Bucharest), 68, no. 2, 2017, p. 215.

12. MARCUS, M.-I., MITIU, M. A., VLAD, M., MINCU, M., GHTA, G., ANGHEL, A.-M., Rev. Chim. (Bucharest), 69, no. 3, 2018, p. 618.

13. RESETAR-DEAC, A.-M., DIACU, E., U.P.B. Sci. Bull., Series B, 77, no. 3, 2015, p. 59.

14. MITIU, M. A., MARCUS, M.-I., VLAD, M., BALACEANU, C. M., Rev. Chim. (Bucharest), 69, no. 3, 2018, p. 571.
15. ANGHEL, A.-M., DIACU, E., ILIE, M., PETRESCU, A., GHTA, G., MARINESCU, F., DEAK, Gy., Rev. Chim. (Bucharest), 67, no. 11, 2016, p. 2151.

16. IONESCU, P., RADU, V. M., DEAK, GY., IVANOV, A. A., DIACU, E., Rev. Chim. (Bucharest), 66, no. 8, 2015, p. 1088.

17. *** Source Control of Priority Substances in Europe - SOCOPSE, Report on Danube case study, Project contract no. 037038, 2006-2009 18. *** Water quality - Sampling - Part 6: Guidance on sampling of rivers and streams

19. *** Water quality. Sampling. Part 12: Guidance on sampling of bottom sediments

20. *** Order of the Ministry of Environment and Water Management no. 161/2006, Official Journal of Romania, no. 511/13.06.2006, for the approval of the Normative on the Classification of Surface Water Quality in order to establish the ecological status of the water bodies 21. ZHUANG W., GAO, X., PLOS ONE, 9, no. 4, 2014, https://doi.org/ 10.1371/journal.pone.0094145

22. GASPAROTTI, C., EuroEconomica, ISSN: 1582-8859 (online), 33, no.1, 2014.

23. ILIE, M., MARINESCU, F., ANGHEL, A.-M., GHITA, G., DEAK, Gy., RAISCHI, M., CIRSTINOIU, C., MATEI, M., ZAMFIR, S., IJ ES (IPA journals), 1,2016, p. 230.

Manuscript received: 19.12 .2018 